Available online on 15.02.2021 at http://jddtonline.info
(C) 2011-21, publisher and licensee JDDT, This is an Open Access article which permits
unrestricted non-commercial use(CC By-NC), provided the original work is properly cited
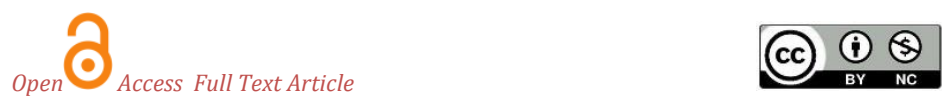

Research Article

\title{
Determinants of adherence to ARVs in HIV+ women enrolled in the PMTCT program in the West and North Regions of Cameroon
}

\author{
Armand Tiotsia Tsapi*1,2, Eric Defo Tamgno2,3, Eméline Zogning Makemjio2,4, Ezechiel Ngoufack Jagni \\ Semengue ${ }^{2,4,5}$, Ghyslaine Bruna Djeunang Dongho ${ }^{1}$, Efeutmecheh Sangong Rose ${ }^{6}$, Hervé Davy Tongue Kamga ${ }^{2}$, \\ Georges Nguefack-Tsague ${ }^{8}$, Gianluca Russo ${ }^{1}$, Martin Sanou Sobze ${ }^{7}$ \\ ${ }^{1}$ Department of Infectious Diseases, Microbiology and Public Health; Sapienza University of Rome, Rome, Italy. \\ ${ }^{2}$ Faculty of Sciences and Technology, Evangelical University of Cameroon, Bandjoun, Cameroon. \\ ${ }^{3}$ Department of Public Health, Epidemiology and Health Economics, University of Liege, Liege, Belgium. \\ ${ }^{4}$ Department of experimental medicine, University of Roma Tor Vergata, Rome, Italy \\ ${ }^{5}$ Chantal Biya International Reference Center, for research on HIV prevention and management, Yaoundé, Cameroon \\ ${ }^{6}$ Regional Technical Group for the Fight against HIV/AIDS, Northwest Region, Cameroon \\ ${ }^{7}$ Faculty of Medicine and Pharmaceutical Sciences, University of Dschang, Dschang, Cameroon \\ ${ }^{8}$ Department of Public Health, Faculty of Medicine and Biomedical Sciences, University of Yaounde I, Cameroon.
}

\section{Article Info:}

\section{Article History:}

Received 10 Dec 2020;

Review Completed 22 Jan 2021

Accepted 02 Feb 2021;

Available online 15 Feb 2021

*Address for Correspondence:

Armand Tiotsia Tsapi,

${ }^{1}$ Department of Infectious Diseases, Microbiology and Public Health; Sapienza University of Rome, Rome, Italy. ${ }^{2}$ Faculty of Sciences and Technology, Evangelical University of Cameroon, Bandjoun, Cameroon.

\section{Cite this article as:}

Tiotsia Tsapi A, Defo Tamgno E, Zogning Makemjio E, Ngoufack Jagni Semengue E, Djeunang Dongho GB, Sangong Rose E, Tongue Kamga HD, Nguefack-Tsague G, Russo G, Sanou Sobze M, Determinants of adherence to ARVs in HIV+ women enrolled in the PMTCT program in the West and North Regions of Cameroon, Journal of Drug Delivery and Therapeutics. 2021; 11(1-s):62-70 DOI: http://dx.doi.org/10.22270/jddt.v11i1-s.4712

\section{Abstract}

Background: According to UNAIDS 2019, 52\% of people worldwide living with HIV is on antiretrovirals (ARVs), HIV positive women representing $80 \%$ of them. This study aimed at highlighting the determinants of adherence to ARVs for HIV positive women enrolled in PMTCT programs in the West and North Regions of Cameroon.

Methods: A descriptive and analytical cross-sectional study was carried out from February to September 2019 in three treatment centres in the West (Bafoussam Regional Hospital and Dschang District Hospital) and North (Garoua Regional Hospital) regions in Cameroon. Data were collected using a questionnaire administered face to face and encoded in Excel 2013, then analyzed using SAS version 7.8. P-values $<0.05$ were considered statistically significant

Results: One thousand (1000) women were interviewed. The mean age was $17 \pm 2$ years (Range: 12 - 67 years); 231 (23.1\%) were single. Overall, the prevalence of ARTadherence was $68.6 \%$. After multivariate analysis using multiple logistic regression; having one HIV-infected children $(\mathrm{aOR}=60.9 ; 95 \% \mathrm{CI}=[7.6 ; 489.1] ; \mathrm{P}=0.001)$, nondisclosure of serological status with the spouse/boyfriend $(\mathrm{aOR}=25.2 ; 95 \% \mathrm{CI}=[9.2 ; 68.9]$; $\mathrm{P}<0.001)$, not being educated (aOR=7.7; 95\%CI=[4.4; 13.3]; $\mathrm{P}<0.001)$; and taking ARVs once or less daily $(\mathrm{aOR}=50 ; 95 \% \mathrm{CI}=[20.0 ; 100.0] ; \mathrm{P}<0.001)$ were four risk factors for nonadherence.

Conclusion: ART-adherence among Cameroonian pregnant women is still very far below UNAIDS target (95\%), with four potential key determinants identified. As we are progressively moving towards the elimination of HIV vertical transmission in 2030 as advocated by UNAIDS, local policies should be reinforced in order to consolidate the strides made so far.

Keywords: HIV, PMTCT, Pregnancy, Adherence, option B+, Cameroon.

\section{INTRODUCTION}

In line with the multiple efforts undertaken to improve access to antiretroviral drugs (ARVs) in sub-Saharan Africa, ARV coverage among people living with HIV (PLWHIV) in Cameroon has increased from $0 \%$ in 2003 to $22 \%$ in 2014 . However, the success of HIV programs does not depend exclusively on access to ARVs, but also on retention in care and adherence to ARVs. This is critical to achieving viral load suppression, preventing the emergence of new HIV resistant strains, reducing transmission and the number of HIVrelated deaths ${ }^{1}$. The use of antiretroviral therapy (ART) is a fundamental strategy proposed by the World Health
Organization (WHO) for the prevention of mother-to-child transmission (PMTCT) of HIV 2 . This strategy has led to a considerable reduction in the morbidity and mortality rates associated with HIV/AIDS ${ }^{3}$. In 2019, 37.9 million (32.7 million-44.0 million) people were living with HIV worldwide. These included 36.2 million (31.3 million-42.0 million) adults and 1.7 million (1.3 million-2.2 million) children ( $<15$ years). In 2010, 23.3 million (20.5 million-24.3 million) people living with HIV had access to antiretroviral treatment, but only $54 \%(37-73 \%)$ of children aged $0-14$ years and $68 \%(52-82 \%)$ of adult women aged 15 years and older had access to treatment 4 . 
Sub-Saharan Africa has the highest burden of HIV in the world. Guidelines and programs for HIV prevention plans should be designed following an assessment of the costeffectiveness of country-level activities, with the aim of contextualizing interventions to achieve much better results 5. Despite the fact that significant progress has been made in eliminating mother-to-child transmission of HIV in subSaharan Africa, much remains to be done 6. In 2019, in Cameroon, 540000 people were living with HIV. The incidence of HIV among the population during that year was $1.02 \%$ for all age groups combined. HIV prevalence, that is, the percentage of people living with HIV, was 3.6\% among adults (between 15 and 49 years). 23,000 new HIV infections were registered. 18000 people died of HIVrelated causes. Antiretroviral coverage among pregnant women living with HIV to prevent transmission of the virus to their children was $80 \%$, preventing 4,200 new infections among newborns. The rate of early infant diagnosis, that is, the percentage of HIV-exposed babies tested before their eighth week of age, reached $61 \%$ in $2018{ }^{7}$.

The most highlighted barriers to achieving PMTCT of HIV are late initiation of antiretroviral treatment, non-adherence and non-involvement of men in the process. Hence, the need to implementing the 90-90-90 goals for the elimination of MTCT is imperial 8,9. However, because HIV-infected pregnant women experience a great psychological crisis, health care providers need to use an approach that is as user-friendly as possible 10 .

Many studies conducted in different regions of Cameroon show some disparity in the prevalence of adherence to ARVs among PMTCT women. For example, a prevalence of adherence to ARVs of $65.2 \%$ was reported in the study conducted by Tebeu et al. in the Health Districts of Ndop and Fundong, North West Region of Cameroon 11, another of $67.5 \%$ in 2012 in the study by Perfura et al., at the Jamot Center in Yaoundé 12 , and finally a prevalence of $62.7 \%$ in the Kumbo Health District 13; compared to a prevalence of 87.1\% in Ethiopia ${ }^{14}$. Similarly, several studies conducted in Cameroon and sub-Saharan Africa show that demographic and socio-economic factors, patient-related factors, factors related to health care systems and ART, stigmatization, transportation costs, deprivation of food and whether or not the woman's HIV status is shared with her partner, family and community, educational level, occupation, and lack of knowledge of the spouse's HIV status can positively or negatively influence adherence to ART for HIV-positive women 1-3,11-15.

However, the factors that impede adherence to antiretroviral treatment in Cameroon are not well known and may be influenced by the specific lifestyle habits of each Cameroonian region. For a much better efficiency of local ARVs programs, it is essential to identify barriers to adherence and then determine and implement appropriate measures to promote and improve it.

\section{MATERIALS AND METHODS}

This was a cross-sectional descriptive and analytical study conducted from February to September 2019 in three treatment centres of PLWHIV, belonging to the Western (Bafoussam Regional Hospital and Dschang District Hospital) and Northern (Garoua Regional Hospital) regions. This study aimed to highlight the determinants of adherence to ARVs among a cohort of women followed within the aforementioned healthcare facilities in PMTCT programs.
Data was collected using a questionnaire administered faceto-face to all PMTCT women who came for consultations or for ARV supplies during our survey. The minimum sample size for our study was calculated using the standard formula for cross sectional studies 16 which resulted in 395 women. Once collected, the data were entered and processed using Excel 2013 software and analyzed using SAS version 7.8 software.

From the descriptive analysis, we extracted frequencies and proportions. Adherence to treatment was assessed by combining two methods. The direct method taking into account clinical parameters such as CD 4 count ( $\geq 350$ CD4), Viral Load ( $\leq 50$ copies) and the indirect method taking into account the intrinsic elements of the patient like the therapeutic protocol, the absence of annoying postmedication manifestations. A patient with a positive score (greater than or equal to 3 ) to both methods was declared adherent. Univariate analyses were carried out using a Chi square test and multivariate analyses by the binary logistic regression method using adherence or non-adherence to treatment as the dependent variable. A significance level of 0.05 and odds ratio value compared to the number one (1) allowed us to decide on the relationship between the variable of interest (adherence) in our study and the independent variables. For the profession, we have divided it into three sectors, namely primary (farmer, housewife, other without qualification), secondary (craftsman, merchant) and tertiary (civil servant, retired).

Ethical approval: To conduct this study, we obtained the ethical approval Number CEN¹58/CRERSH/2019 of the Center Regional Committee for Ethics and Research in Human Sciences.

Consent of participants: In this study, informed written consent was obtained from each participant, prior to his inclusion in the study.

\section{RESULTS}

\section{Socio-demographic Features}

A total of 1000 women equally distributed in the West and North Regions of Cameroon (500 women per region) took part in this study. According to age, women participating in this study were relatively young ([12 - 34] years); with very few among them (26\%; 260/1000) living in rural areas. According to ethnicity, the bamileké women were more represented (57.2\%; 572/1000) and 72.4\% (724/1000) women in our study population were Christian women. About 18.4\% (184/1000) participants never went to school and where thus considered as not-educated. According to civil status, we counted $44.4 \%$ (444/1000) single women, $47.5 \%$ (475/1000) married, 3.9\% (39/1000) divorced and $4.2 \%(42 / 1000)$ widows. Among the married women, $48.21 \%$ (229/475) belonged to a polygamous home. As regarding the legal spouses (for the married women) and the boyfriends (for both the single, the divorced and even some widows) about $23.69 \%$ (218/920) of them were HIVnegative. Finally, 25.2\% (252/1000) of women declared not having any children while $36.5 \%(365 / 1000)$ declared to have more than four living children; among all these living pregnancies, $8.82 \%(66 / 748)$ women only had at least one HIV-infected children; with a median age of 3 [interquartile range: 0.5 - 6] years old for these infected children. Table1 below gives in-depth details of all socio-demographic parameters. 
Table 1: Socio-demographic characteristics of sampled PMTCT women

\begin{tabular}{|c|c|c|c|}
\hline Variables & Term and Conditions & Total & Percentages \\
\hline \multirow{2}{*}{$\operatorname{Age}(N=1000)$} & {$[12-34]$} & 727 & 72.7 \\
\hline & [35-67] & 273 & 27,3 \\
\hline \multirow{3}{*}{ Residential Area $(N=1000)$} & Rural Areas & 260 & 26 \\
\hline & Urban Areas & 188 & 18.8 \\
\hline & Semi-urban Areas & 552 & 55.2 \\
\hline \multirow{4}{*}{ Ethnicity $(N=1000)$} & Bamiléké & 582 & 58.2 \\
\hline & Foufouldé & 81 & 8.1 \\
\hline & Toupouri & 241 & 24,1 \\
\hline & Haoussa & 96 & 9.6 \\
\hline \multirow{3}{*}{ Religion $(N=1000)$} & Christian & 724 & 72.4 \\
\hline & Muslim & 179 & 17.9 \\
\hline & Other & 97 & 9.7 \\
\hline \multirow{4}{*}{$\begin{array}{l}\text { Level of Education } \\
(N=1000)\end{array}$} & Not educated & 184 & 18.4 \\
\hline & Primary & 352 & 35.2 \\
\hline & Secondary & 359 & 35.9 \\
\hline & University & 105 & 10.5 \\
\hline \multirow{4}{*}{ Civil Status $(N=1000)$} & Single & 444 & 44.4 \\
\hline & Married & 475 & 47.5 \\
\hline & Divorced & 39 & 3.9 \\
\hline & Widow & 42 & 4.2 \\
\hline \multirow{2}{*}{$\begin{array}{l}\text { Matrimonial regime } \\
(N=475)\end{array}$} & Polygamous & 229 & 48.21 \\
\hline & Monogamous & 246 & 51.79 \\
\hline \multirow{3}{*}{$\begin{array}{l}\text { HIV status of the partners } \\
(N=920)\end{array}$} & Positive & 616 & 67.0 \\
\hline & Negative & 218 & 23.7 \\
\hline & Unknown & 86 & 9.3 \\
\hline \multirow{4}{*}{$\begin{array}{l}\text { Number of Children } \\
(N=1000)\end{array}$} & No children & 252 & 25.2 \\
\hline & 1 child & 173 & 17.3 \\
\hline & 2-4 children & 210 & 21.0 \\
\hline & Above 4 children & 365 & 36.5 \\
\hline \multirow{3}{*}{$\begin{array}{l}\text { Number of HIV-infected } \\
\text { Children ( } N=748 \text { women) }\end{array}$} & None & 682 & 91.2 \\
\hline & 1 HIV(+) child & 37 & 4.9 \\
\hline & More than 1 HIV(+) child & 29 & 3.9 \\
\hline \multirow{3}{*}{ Profession $(N=1000)$} & Primary sector & 728 & 72.8 \\
\hline & Secondary sector & 203 & 20.3 \\
\hline & Tertiary sector & 69 & 9 \\
\hline
\end{tabular}




\section{Social behaviours and others parameters}

Disclosure of the serological status with spouse/boyfriend and family members was not systematic in the study population; about $21.7 \%(217 / 1000)$ and $44 \%(440 / 1000)$ women respectively had not disclosed their serological status in either case. Similarly, 34.4\% (344/1000) and $29.4 \%(294 / 1000)$ of the spouses and other family members respectively were not informed of their treatment. As a result, 35.1\% (351/1000) of the women interviewed did not receive support from family members. (See table 2 for more clarifications)

Table 2: Disclosure of the serological status with the family

\begin{tabular}{|c|c|c|}
\hline Characteristics & Total & Percentage (\%) \\
\hline \multicolumn{3}{|c|}{ Disclosure of the status with spouse/boyfriend $(N=1000)$} \\
\hline Yes & 783 & 78.3 \\
\hline No & 217 & 21.7 \\
\hline \multicolumn{3}{|l|}{ Spouse informed of the treatment $(N=1000)$} \\
\hline Yes & 656 & 65.6 \\
\hline No & 344 & 34.4 \\
\hline \multicolumn{3}{|c|}{ Disclosure of the status with other family members $(N=1000)$} \\
\hline Yes & 560 & 56 \\
\hline No & 440 & 44 \\
\hline \multicolumn{3}{|c|}{ Other members (friends) aware of your treatment? $(\mathrm{N}=1000)$} \\
\hline Yes & 706 & 70.6 \\
\hline No & 294 & 29.4 \\
\hline \multicolumn{3}{|c|}{ Do you receive support from these members $(N=1000)$} \\
\hline Yes & 649 & 64.9 \\
\hline No & 351 & 35.1 \\
\hline
\end{tabular}

\section{Antiretroviral therapy and treatment outcomes}

Respectively $2.4 \%(24 / 1000)$ and $3.7 \%$ (37/1000) of the women surveyed admitted having difficulties meeting the doctor responsible for their clinical follow-up and having difficulties meeting the pharmacist in charge of dispensing
ARVs. However, all (100\%) of them declare that they get help from their doctors and care providers when necessary and are satisfied (99.6\%) with the advice given by health workers to facilitate their experience with the disease. (Table 3).

Table 3: PMTCT woman interaction with care providers

\begin{tabular}{|c|c|c|}
\hline Characteristics & Total & Percentage (\%) \\
\hline \multicolumn{3}{|l|}{ Difficulties in meeting the Doctor $(\mathrm{N}=1000)$} \\
\hline Yes & 24 & 2.4 \\
\hline No & 976 & 97.6 \\
\hline \multicolumn{3}{|l|}{ Getting help when needed $(N=1000)$} \\
\hline Yes & 1000 & 100 \\
\hline No & 0 & 0.0 \\
\hline \multicolumn{3}{|c|}{ Satisfaction with advice given by Health Workers $(N=1000)$} \\
\hline Yes & 996 & 99.6 \\
\hline No & 4 & 0.4 \\
\hline \multicolumn{3}{|l|}{ Difficulty meeting the Pharmacist $(N=1000)$} \\
\hline Yes & 37 & 3.7 \\
\hline No & 963 & 96.3 \\
\hline \multicolumn{3}{|c|}{ Member of an association of PLWHIV? (N=1000) } \\
\hline Yes & 562 & 56.2 \\
\hline No & 438 & 43.8 \\
\hline
\end{tabular}


About 94.2\% (942/1000) of the women enrolled were under a first line regimen (2 nucleoside reverse transcriptase inhibitors +1 non-nucleoside reverse transcriptase inhibitors). Only $12.1 \%(121 / 1000)$ of them had a viral load of less than 50 copies/ml and 13.9\% (139/1000) were found with a CD 4 count of more than 350 cells $/ \mathrm{mm}^{3}$.

Embarrassing manifestations at the initiation of ART treatment were encountered in $71.4 \%(714 / 1000)$ of the women surveyed. Vomiting [13\% (130/1000)] and dizziness
$[11.9 \%(119 / 1000)]$ were the most frequently reported symptoms of discomfort after ARV treatment, and these decreased in $20.1 \%(201 / 1000)$ of cases as the drugs were taken. Among our respondents, 52.5 (525/1000) had initiated antiretroviral treatment at least 36 months before our survey and $2.4 \%(24 / 1000)$ of them were taking between two (02) and four (04) ARV tablets per day. Finally, $91 \%(910 / 1000)$ of these women reported a remarkable improvement in their health during the course of the medication. (See table 4 for more clarifications)

Table 4: Antiretroviral therapy and treatment outcomes

\begin{tabular}{|c|c|c|}
\hline Characteristics & Total & Percentage (\%) \\
\hline \multicolumn{3}{|l|}{ Therapeutic protocol $(N=1000)$} \\
\hline 1st line & 942 & 94.2 \\
\hline 2nd line & 58 & 5.8 \\
\hline \multicolumn{3}{|l|}{ Viral load $(N=1000)$} \\
\hline$\leq 50$ copies & 121 & 12.1 \\
\hline$>50$ copies & 879 & 87.9 \\
\hline \multicolumn{3}{|l|}{ CD4 count $(N=1000)$} \\
\hline$\leq 350$ & 861 & 86.1 \\
\hline$>350$ & 139 & 13.9 \\
\hline \multicolumn{3}{|l|}{ ART initiation date $(N=1000)$} \\
\hline Less than 12 months & 107 & 10.7 \\
\hline 12-24 months & 197 & 19.7 \\
\hline 24-36 months & 171 & 17.1 \\
\hline More than 36 months & 525 & 52.5 \\
\hline \multicolumn{3}{|l|}{ Number of ART tablets per day $(N=1000)$} \\
\hline One (01) tab & 806 & 80.6 \\
\hline Two (02) tabs & 170 & 17.0 \\
\hline $2-4$ tabs & 24 & 2.4 \\
\hline \multicolumn{3}{|c|}{ Embarrassing post-medication events $(N=1000)$} \\
\hline Vomiting & 130 & 13.0 \\
\hline Vertigo & 119 & 11.9 \\
\hline Asthenia & 11 & 1.1 \\
\hline All of the above & 16 & 1.6 \\
\hline Nothing & 720 & 72.0 \\
\hline \multicolumn{3}{|c|}{$\begin{array}{l}\text { Evolution of trouble some manifestations with } \\
\text { medication }(N=1000)\end{array}$} \\
\hline Nothing & 720 & 72.0 \\
\hline Decrease & 207 & 20.7 \\
\hline Increase & 2 & 0.2 \\
\hline No change & 71 & 7.1 \\
\hline \multicolumn{3}{|c|}{ Improvement in health since treatment $(N=1000)$} \\
\hline remarkable Improvement & 910 & 91.0 \\
\hline $\begin{array}{l}\text { No Improvement } \\
\text { reatment interruption in the previous ye }\end{array}$ & 90 & 9.0 \\
\hline Yes & 119 & 11.9 \\
\hline No & 881 & 88.1 \\
\hline nowledge of the risks of non-medication & & \\
\hline Yes & 759 & 75.9 \\
\hline No & 241 & 24.1 \\
\hline
\end{tabular}

It was found that $99.2 \%(992 / 1000)$ of the women interviewed contributed in a way or another to their care. About $74.1 \%$ (741/1000) of their contribution was much more related to the cost of transportation to the healthcare facility and the purchase of drugs for opportunistic ISSN: 2250-1177 infections. The monthly contribution quota most frequently mentioned was included in the range of $0-5000 \mathrm{Fcfa}[64.2 \%$ (642/1000)]. However, 57.5\% (575/1000) of the respondents considered this cost to be affordable, as long as it allowed them to regain their health (table5). 
Table 5: Contribution to the therapeutic process

\begin{tabular}{|c|c|c|}
\hline Characteristics & Total & Percentage (\%) \\
\hline \multicolumn{3}{|l|}{ Contribution to Treatment $(N=1000)$} \\
\hline Yes & 992 & 99.2 \\
\hline No & 8 & 0.8 \\
\hline \multicolumn{3}{|l|}{ Elements to Contribute for the Treatment $(N=992)$} \\
\hline Transport (T) & 144 & 14.52 \\
\hline Analysis Fees (AF) & 6 & 0.6 \\
\hline Transport and Analysis Fees & 61 & 6.15 \\
\hline Transport and purchase of drugs (against opportunistic infections) & 741 & 74.7 \\
\hline All of the above & 40 & 4.03 \\
\hline \multicolumn{3}{|l|}{ Cost of contribution $(N=992)$} \\
\hline $0-5000$ FCFA & 642 & 64.72 \\
\hline 5000-10000 FCFA & 170 & 17.14 \\
\hline$>10000$ FCFA & 180 & 18.14 \\
\hline \multicolumn{3}{|l|}{ Appreciation of the burden of the contribution $(N=1000)$} \\
\hline High & 276 & 27.6 \\
\hline Affordable & 575 & 57.5 \\
\hline Good & 149 & 14.9 \\
\hline
\end{tabular}

\section{Overall prevalence of adherence to ARVS}

Combining both direct and indirect methods described above, we came out with a general prevalence in terms of adherence to antiretroviral treatment of around 69.6\% $(696 / 1000)$. Data collected from these women reveal a higher prevalence of adherence to antiretroviral therapy in the North Region than in the West; with respective values of $74.0 \%(370 / 500)$ and 63\% (315/500). Three reasons were given by our respondents to justify non-adherence: forgetfulness (80.5\%), fear of the spouse/boyfriend (12.0\%) and drug stock out (7.5\%).

Table 6: Monitoring of ART- adherence

\begin{tabular}{c|cc}
\hline Characteristics & Total & Percentages (\%) \\
Reasons for Non-adherence to ART (N=1000) & & 80.5 \\
Forgetfulness & 805 & 12.0 \\
Fear of the spouse & 120 & 7.5 \\
Drug stock out & 75 & \\
\hline
\end{tabular}

\section{Key determinants of non-adherence}

With the use of univariate analysis, we were able to come out with 9 key determinants of non-adherence. The region of residence, the level of education, the civil status and matrimonial regime (for the married women in particular), disclosure of serological status, the number of HIV-infected children, the frequency of ARVs uptake per day, the immunological status and finally the level of viral suppression; all showed a statistical significance with respect to non-adherence. As for the region of residence and the marital status, being from the North region or from a polygamous home were risk factors of non-adherence $(\mathrm{p}<0.001,0 \mathrm{O}=1.67$ and $\mathrm{p}<0.001,0 \mathrm{R}=2.54$ respectively). Being educated, married, having more than one HIV-infected child and the disclosure of serological status were found to be protective socio-demographic parameters $(\mathrm{p}<0.001$, $\mathrm{OR}=0.31 ; \mathrm{p}<0.001, \mathrm{OR}=0.16 ; \mathrm{p}=0.002, \mathrm{OR}=0.10$; and $\mathrm{p}<0.001$, $\mathrm{OR}=0.12$ respectively). One time ARVs uptake per day, $\mathrm{CD} 4>$ 350 cells $/ \mathrm{mm}^{3}$ and viral load $<40$ RNA copies/ml were also found to protect against non-adherence within our study population (see table 7). 
Table 7: Multiple logistic regression of significant variables

\begin{tabular}{|c|c|c|c|}
\hline Variables & Not adherent & Adherent & $\begin{array}{c}\text { OR } \\
\text { (p-values) }\end{array}$ \\
\hline \multicolumn{4}{|l|}{ Region of residence } \\
\hline North & 185 & 315 & \multirow{2}{*}{$1.67(<0.001)^{* *}$} \\
\hline West & 130 & 370 & \\
\hline \multicolumn{4}{|l|}{ Level of Education } \\
\hline Schooled women & 216 & 600 & \multirow{2}{*}{$0.31(<0.001)^{* *}$} \\
\hline unschooled & 98 & 86 & \\
\hline \multicolumn{4}{|l|}{ Civil status } \\
\hline Married & 62 & 413 & \multirow[b]{2}{*}{$0.16(<0.001)^{* *}$} \\
\hline Not married (single, divorced and widows) & 252 & 273 & \\
\hline \multicolumn{4}{|l|}{ Matrimonial regime (for those married only) } \\
\hline Polygamy & 42 & 187 & \multirow{2}{*}{$2.54(<0.001)^{* *}$} \\
\hline Monogamy & 20 & 226 & \\
\hline \multicolumn{4}{|l|}{$\begin{array}{l}\text { Disclosure of serological status with the } \\
\text { spouse/boyfriend and the family }\end{array}$} \\
\hline Yes & 178 & 656 & \multirow{2}{*}{$0.12(<0.001)^{* *}$} \\
\hline No & 60 & 26 & \\
\hline \multicolumn{4}{|l|}{ Number of HIV-infected children } \\
\hline More than one & 1 & 28 & \multirow{2}{*}{$0.10(0.002)^{* *}$} \\
\hline 0 or 1 & 187 & 537 & \\
\hline \multicolumn{4}{|l|}{ Frequency of daily uptake of ARVs } \\
\hline One-time & 186 & 620 & \multirow{2}{*}{$0.15(<0.001)^{* *}$} \\
\hline Twice & 128 & 66 & \\
\hline \multicolumn{4}{|l|}{ Immunological status } \\
\hline CD4 $>350$ cells $/ \mathrm{mm}^{3}$ & 29 & 110 & \multirow{2}{*}{$0.53(0.002)^{* *}$} \\
\hline CD4 $<350$ cells $/ \mathrm{mm}^{3}$ & 285 & 576 & \\
\hline \multicolumn{4}{|l|}{ Viral load } \\
\hline Undetectable (<40 copies $/ \mathrm{ml}$ ) & 24 & 97 & \multirow{2}{*}{$0.5(0.001)^{* *}$} \\
\hline Detectable (>40 copies $/ \mathrm{ml}$ ) & 290 & 589 & \\
\hline
\end{tabular}

After multivariate analysis using multiple logistic regression; having one HIV-infected children $(\mathrm{aOR}=60.9 ; 95 \% \mathrm{CI}=[7.6$; 489.1]; $\mathrm{P}=0.001)$, non-disclosure of serological status with the spouse/boyfriend $(\mathrm{aOR}=25.2 ; 95 \% \mathrm{CI}=[9.2 ; 68.9] ; \mathrm{P}<0.001)$, not being educated $(\mathrm{aOR}=7.7 ; 95 \% \mathrm{CI}=[4.4 ; 13.3]$; $\mathrm{P}<0.001)$; and taking ARVs once or less daily $(\mathrm{aOR}=50 ; 95 \% \mathrm{CI}=[20.0$; 100.0]; $\mathrm{P}<0.001$ ) were four risk factors for non-adherence (see table 8).

Table 8: Multiple logistic regression of significant variables

\begin{tabular}{|c|c|c|c|c|c|}
\hline Variables & $\begin{array}{l}\text { Adjusted odd } \\
\text { ratio }\end{array}$ & $\begin{array}{l}\text { 95\% confidence } \\
\text { intervals }\end{array}$ & $\begin{array}{r}\text { Regression } \\
\text { coefficient }\end{array}$ & $\begin{array}{c}\text { Standard } \\
\text { error }\end{array}$ & p-values \\
\hline $\begin{array}{c}\text { Region of residence (West vs. } \\
\text { North) }\end{array}$ & 0.7 & {$[0.4 ; 1.2]$} & -0.36 & 0.26 & 0.16 \\
\hline Disclosure of the status (No vs. Yes) & 25.2 & {$[9.2 ; 68.9]$} & 3.22 & 0.51 & $<0.001^{* *}$ \\
\hline $\begin{array}{c}\text { Daily arvs uptake (One or less vs } \\
\text { more than one) }\end{array}$ & 50.0 & {$[20.0 ; 100.0]$} & -3.74 & 0.39 & $<0.001^{* *}$ \\
\hline $\begin{array}{c}\text { Number of HIV-infected children } \\
\text { (more than one vs. one) }\end{array}$ & 60.9 & {$[7.6 ; 489.1]$} & 4.11 & 1.06 & $0.001^{* *}$ \\
\hline $\begin{array}{c}\text { Level of education (wasn't schooled } \\
\text { vs. Schooled) }\end{array}$ & 7.7 & {$[4.4 ; 13.3]$} & 2.03 & 0.28 & $<0.001^{* *}$ \\
\hline $\begin{array}{c}\text { Civil status (unmarried vs. } \\
\text { married) }\end{array}$ & 1.6 & {$[0.9 ; 2.6]$} & 0.46 & 0.25 & 0.06 \\
\hline $\begin{array}{c}\text { CD4 count }(>350 \text { vs. }<350 \\
\left.\text { cells } / \mathrm{mm}^{3}\right)\end{array}$ & 0.8 & {$[0.2 ; 3.6]$} & -0.20 & 0.76 & 0.78 \\
\hline $\begin{array}{c}\text { Viral load }(<40 \text { vs. }>40 \text { RNA } \\
\text { copies } / \mathrm{ml} \text { ) }\end{array}$ & 0.3 & {$[0.06 ; 1.9]$} & -1.03 & 0.84 & 0.22 \\
\hline
\end{tabular}




\section{DISCUSSION}

This study conducted among HIV-positive pregnant women under option $\mathrm{B}+$ in the regions of North and West Cameroon aimed to identify the determinants of therapeutic adherence. Indeed, achieving the WHO goal of eliminating all vertical transmission of HIV remains a dilemma in resource-limited countries including Cameroon. The main objective of PMTCT interventions is to reduce barriers at each step of the continuum of care to successfully prevent vertical transmission of HIV. Despite the adoption of Option B+ and the combination of ARV delivery services at antenatal clinics, these barriers remain problematic for mother-child couples.

Our results thus reveal an overall adherence level of $68.6 \%$, i.e. $74.2 \%$ and $63 \%$ for the Northern and Western regions respectively. A much lower prevalence has been reported in Nigeria 15 where only $32.7 \%$ of HIV-positive pregnant women under option B+ reported $100 \%$ ART consumption over a four-day booster period. Another study in Tanzania reported low adherence of $26.3 \%$ and $61.1 \%$ among respondents living in urban and rural settings, respectively 17. However, this is far below the $81.4 \% 18,87.1 \%{ }^{14}$ and $89 \%$ 19 found in northern Ethiopia and Kenya by other studies. Despite the differences observed among these African settings these figures are still far below the $95 \%$ recommended in order to ensure a zero risk of infection of the virus in newborns but also to prevent the occurrence of resistance.

No association between age and ART adherence was found in our study. Similar results have also been obtained by many other studies documented that found no association between maternal age and ART adherence 20,21 .

As in many previous studies conducted in sub-Saharan Africa, sharing HIV status with one's spouse proved to be a real facilitator of adherence in pregnant women $(p=0.0001)$, decreasing the probability of adherence by up to 4.88 times in those whose status remained unknown to the spouse. A similar result was found by Ebuy, H., Yebyo et al in Ethiopia where disclosure of HIV status was positively associated with good adherence increasing up to 4.2 times among women who had disclosed their status to their spouses 14 . According to WHO globally, pregnant women in sub-Saharan Africa have the lowest rate of disclosure of HIV status ${ }^{22}$. Fear of sharing HIV status with partners, family or community remains a major barrier to treatment adherence and use of PMTCT services 2,15,23,24. In the same logic, the daily frequency of ARV use emerges as an element influencing therapeutic adherence. Indeed, women who had to take their medication twice a day were less adherent $(p=0.0001)$ than those who were entitled to a single dose. Indeed, it is more difficult to have to hide twice a day to take a medication with someone who shares our daily life night and day and/or to miss doses if we do not have the support of a spouse. A review conducted in 2014 by Hodgson, reveals that sharing status with one's spouse and being able to benefit from his or her support and participation throughout pregnancy significantly improves women's adherence and retention during the PMTCT program ${ }^{25}$. The need to further mobilize male involvement in PMTCT programs is essential over time if we are to increase women's adherence to antiretroviral therapy and also eliminate vertical transmission of HIV.

Women's education level is identified in our study as influencing adherence to antiretroviral therapy. Indeed, women with higher education levels were 5.43 (Pvalue $<0.0001$ ) times more adherent compared to women with no education. A similar result was found by Tarekegn et al. in 2019 in a study of pregnant women on antiretroviral therapy in six public health facilities in Ethiopia. In this study, a significant association was found between educational attainment and adherence to ART; women with at least primary education were five times more likely to adhere to ART than those who could not read or write [OR $4.54\left(95 \%\right.$ CI; 1.72-11.95)] ${ }^{3}$. Similarly, many other studies have made the same finding 2,15.

In our study, an association between multiparity and therapeutic adherence was found. Indeed, women with more than 4 children were more adherent than those with fewer children. Similar results were obtained in Zimbabwe ${ }^{26}$ and Nigeria ${ }^{27}$. This could be explained by the fact that the latter had already been enrolled in the PMTCT program at least once in a previous pregnancy and had been satisfied with the services and outcome due to the negative serological status of their children. As a result, they were more willing to adhere to the program than those who had been enrolled for the first time. This finding was also found by Murithi et al, in a study conducted in Kenya ${ }^{28}$. Also in a study conducted in Uganda in 2017, some mothers reported discontinuing ART after losing their babies or even after delivery or when they stopped breastfeeding. Health workers in PMTCT services therefore have a dual responsibility to sensitize women on the importance of adherence to ART during and after pregnancy and even after weaning and adherence to medically prescribed dosages 29 . The commitment and adherence of expectant mothers who are enrolled in the program will depend on the effectiveness of the results obtained.

Limitation of this study includes selection bias on the field or the fact that we did not use a robust model in multiregression analysis.

\section{CONCLUSION}

This study was meant to establish a relationship between the socio-cultural and biological parameters and the determinants of non-adherence to ARVs among a PMTCT cohort. Indeed, the cohort of women included in this study came from two regions with totally different cultures and behaviors. Only 4 parameters were more or less strongly statistically significant as regards non-adherence after multiregression analysis. These results suggest that effective prevention of non-adherence among PMTCT women should take into consideration strategies to encourage disclosure of serological status among close relatives, women's education and ART involving one-time drugs uptake per day. Also, as we are progressively moving towards the elimination of HIV vertical transmission in 2030 as advocated by UNAIDS, all barriers to the continuum of care should be identify and tackle adequately according to local sets.

Acknowledgments: The authors would like to express their gratitude to all study participants for their collaboration, the clinical staff for their support, and the local authorities for facilitating this research.

Author's Contribution: ATT, GR, MSS, GBDD, EDT, EZM Conception and design of the survey; ATT, Data collection; ATT, EDT, EZM, ENJS Data analysis; ATT, EDT, EZM, GNT, ENJS Interpretation of results; ATT, GR, MSS, GBDD, EDT, EZM, TKHD, GNT, ENJS; Drafting of the manuscript; All authors were involved in critical revision of the manuscript and all authors approved the final version to be published. All authors agree to be accountable for all aspects of the work in ensuring that questions related to the accuracy or integrity of any part of the work are appropriately investigated and resolved and declare to have 
confidence in the integrity of the contributions of their coauthors.

Conflict of interests: The authors declare that they do not have any conflict of interest.

Funding: This work did not receive funding.

\section{Références}

1. Fonsah JY, Njamnshi AK, Kouanfack C, Qiu F, Mbanya D, Heaton $\mathrm{R}$, et al. Adherence to Antiretroviral Therapy ( ART ) in ' Cameroon: Association with Yaounde Opportunistic Infections , Depression, ART Regimen and Side Effects. 2017; 1-19.

2. Omonaiye O, Kusljic S, Nicholson P, Manias E. Medication adherence in pregnant women with human immunodeficiency virus receiving antiretroviral therapy in sub-Saharan Africa: A systematic review. BMC Public Health. 2018; 18(1):1-20.

3. Tarekegn M. Adherence to option $\mathrm{b}+$ and associated factors among pregnant women on pmtct services at public health facilities of east shawa zone, oromia, ethiopia. 2017; 1-7.

4. Onusida. Statistiques mondiales sur le Vih en 2019 [Internet]. 2019 [cited 2019 Oct 22]. p. 1. Available from: https://www.unaids.org/fr/regionscountries/countries/camero on

5. Sarkar S, Corso P, Ebrahim-Zadeh S, Kim P, Charania S, Wall K. Cost-effectiveness of HIV Prevention Interventions in SubSaharan Africa: A Systematic Review. EClinicalMedicine [Internet]. 2019; 10:10-31. Available from: https://doi.org/10.1016/j.eclinm.2019.04.006

6. Adetokunboh OO, Oluwasanu M. Eliminating mother-to-child transmission of the human immunodeficiency virus in subSaharan Africa: The journey so far and what remains to be done. J Infect Public Health [Internet]. 2016; 9(4):396-407. Available from: http://dx.doi.org/10.1016/j.jiph.2015.06.010

7. PEPFAR. CAMEROON Country Operational Plan COP 2020 Strategic Direction Summary. 2020.

8. Auvinen J, Kylmä J, Välimäki M, Bweupe M, Suominen T. Barriers and Resources to PMTCT of HIV: Luba-Kasai Men's Perspective in Lusaka, Zambia. J Assoc Nurses AIDS Care. 2013; 24(6):55468.

9. Yah CS, Tambo E. Why is mother to child transmission (MTCT) of HIV a continual threat to new-borns in sub-Saharan Africa (SSA). J Infect Public Health [Internet]. 2019; 12(2):213-23. Available from: https://doi.org/10.1016/j.jiph.2018.10.008

10. Msellati P. Improving mothers' access to PMTCT programs in West Africa: A public health perspective. Soc Sci Med [Internet]. 2009; 69(6):807-12. Available from: http://dx.doi.org/10.1016/j.socscimed.2009.05.034

11. Tebeu PM, Vifeme MM, Nshom EM. Determinants of non- adherence to antiretroviral therapy among Option B + cases in Ndop and Fundong health districts , Northwest Region , Cameroon. 2019; (October 2018):112-4.

12. Pefura-yone EW, Soh E, Pascal A, Dodo A, Kuaban C. Nonadherence to antiretroviral therapy in Yaounde : Prevalence , determinants and the concordance of two screening criteria. ] Infect Public Health [Internet]. 2013; 6(4):307-15. Available from: http://dx.doi.org/10.1016/j.jiph.2013.02.003

13. Atanga PN, Ndetan HT, Fon PN, Meriki HD, Muffih TP, Achidi EA. Using a composite adherence tool to assess ART response and risk factors of poor adherence in pregnant and breastfeeding HIV-positive Cameroonian women at 6 and 12 months after initiating option B +. 2018; 9:1-10.

14. Ebuy H, Yebyo H, Alemayehu M. International Journal of Infectious Diseases Level of adherence and predictors of adherence to the Option B + PMTCT programme in Tigray , northern Ethiopia. Int J Infect Dis [Internet]. 2015; 33:123-9. Available from: http://dx.doi.org/10.1016/j.ijid.2014.12.026
15. Omonaiye $\mathrm{O}$, Kusljic S, Nicholson P, Mohebbi M, Manias E. International Journal of Infectious Diseases Post Option B + implementation programme in Nigeria : Determinants of adherence of antiretroviral therapy among pregnant women with HIV. Int J Infect Dis [Internet]. 2019; 81:225-30. Available from: https://doi.org/10.1016/j.ijid.2019.02.014

16. Pourhoseingholi MA, Vahedi M, Rahimzadeh M. Sample size calculation in medical studies. Gastroenterol Hepatol from Bed to Bench. 2013; 6(1):14-7.

17. Zacharius KM, Basinda N, Marwa K, Mtui EH, Kalolo A, Kapesa A. Low adherence to Option B + antiretroviral therapy among pregnant women and lactating mothers in eastern Tanzania. PLoS One. 2019; 14(2):1-12.

18. Tesfaye DJ, Hibistu DT, Abebo TA, Asfaw FT, Lukas K, Laelago T, et al. Option B plus antiretroviral therapy adherence and associated factors among HIV positive pregnant women in Southern Ethiopia. BMC Pregnancy Childbirth. 2019; 19(1):1-8.

19. Ayuo P, Musick B, Liu H, Braitstein P, Nyandiko W, OtienoNyunya B, et al. Frequency and factors associated with adherence to and completion of combination antiretroviral therapy for prevention of mother to child transmission in western Kenya. J Int AIDS Soc. 2013; 16.

20. Okawa S, Chirwa M, Ishikawa N, Kapyata H, Msiska CY, Syakantu $\mathrm{G}$, et al. Longitudinal adherence to antiretroviral drugs for preventing mother-to-child transmission of HIV in Zambia. BMC Pregnancy Childbirth [Internet]. 2015; 1-10. Available from: http://dx.doi.org/10.1186/s12884-015-0697-7

21. Schnack A, Rempis E, Decker S. Prevention of Mother-to-Child Transmission of HIV in Option B + Era : Uptake and Adherence During Pregnancy. 2016; 30(3):110-8.

22. WHO. HIV Status Disclosure to Sexual Partners: Rates, Barriers and Outcomes for Women [Internet]. World Health Organization; 2004. Available from: http://www.who.int/genderequityrights/knowledge/9241590734/en/

23. Colombini M, Stöckl H, Watts C, Zimmerman C, Agamasu E, Mayhew SH. Factors affecting adherence to short-course ARV prophylaxis for preventing mother-to-child transmission of HIV in sub-Saharan Africa: A review and lessons for future elimination. AIDS Care - Psychol Socio-Medical Asp AIDS/HIV. 2014; 26(7):914-26.

24. Gourlay A, Birdthistle I, Mburu G, Iorpenda K, Wringe A. Barriers and facilitating factors to the uptake of antiretroviral drugs for prevention of mother-to-child transmission of HIV in subSaharan Africa: A systematic review. J Int AIDS Soc. 2013; 16:121.

25. Hodgson I, Plummer ML, Konopka SN, Colvin CJ, Jonas E, Albertini J, et al. A systematic review of individual and contextual factors affecting ART initiation, adherence, and retention for HIV-infected pregnant and postpartum women. PLoS One. 2014; 9(11).

26. Kuonza LR, Tshuma CD, Shambira GN, Tshimanga M. Nonadherence to the single dose nevirapine regimen for the prevention of mother-to-child transmission of HIV in Bindura town, Zimbabwe: A cross-sectional analytic study. BMC Public Health. 2010;10:1-8.

27. Joseph A, Ogah OE, Robinson O, Matthew NI. Determinants of Adherence to Antiretroviral Therapy among HIV-Positive Women Accessing Prevention of Mother to Child Transmission Services in Ebonyi State , Nigeria. 2018; 248-53.

28. Murithi LK, Masho SW, Vanderbilt AA. Factors Enhancing Utilization of and Adherence to Prevention of Mother-to-Child Transmission (PMTCT) Service in an Urban Setting in Kenya. AIDS Behav. 2015; 19(4):645-54.

29. Buregyeya E, Naigino R, Mukose A, Makumbi F, Esiru G, Arinaitwe J, et al. Facilitators and barriers to uptake and adherence to lifelong antiretroviral therapy among HIV infected pregnant women in Uganda: A qualitative study. BMC Pregnancy Childbirth. 2017; 17(1):1-9. 